Economics Development Analysis Journal

\title{
Elastisitas Transmisi Harga Komoditas Cabai Merah di Jawa Tengah
}

\author{
Tiara Adi Kusumah ${ }^{\bowtie}$
}

Jurusan Ekonomi Pembangunan, Fakultas Ekonomi, Universitas Negeri Semarang

\begin{tabular}{|c|c|}
\hline \multirow{2}{*}{$\begin{array}{l}\text { Article } \\
\text { Information }\end{array}$} & Abstrak \\
\hline & Penelitian ini bertujuan untuk mengetahui : (1) struktur pasar produksi cabai merah di Jawa Tengah. \\
\hline $\begin{array}{l}\text { Hisrtory of Article } \\
\text { Diterima April } 2018 \\
\text { Disetujui Juni } 2018 \\
\text { Dipublikasikan Agustus } \\
2018\end{array}$ & $\begin{array}{l}\text { (2) Menganalisis elastisitas transmisi harga cabai merah ditingkat petani dan tingkat pedagang di } \\
\text { Kabupaten Magelang, Temanggung dan Brebes. Alat analisis yang digunakan adalah analisis rasio } \\
\text { konsentrasi }(\mathrm{CRn}) \text { dan analisis elastisitas transmisi harga }(\mathrm{Et}) \text { digunakan regresi linear sederhana. } \\
\text { Hasil penelitian menunjukan bahwa (1) Struktur pasar produksi yang terbentuk di jawa tengah } \\
\text { secara umum bersifat oligopsoni ketat. (2) Hasil elastisitas transmisi harga disimpulkan bahwa di } \\
\text { Kabupaten Magelang, Temanggung bersifat elastis }(\mathrm{E}>1) \text {. Sedangkan Brebes bersifat inelastis }(\mathrm{E}<1)\end{array}$ \\
\hline $\begin{array}{l}\text { Keywords: } \\
\text { Struktur Pasar, Elastisitas } \\
\text { Transmisi Harga }\end{array}$ & $\begin{array}{l}\text { yang artinya kepekaan perubahan harga di tingkat petani lebih kecil dari pada perubahan harga di } \\
\text { tingkat pedagang. Petani sebagai produsen belum menerima harga yang baik yang dibayarkan oleh } \\
\text { pedagang. Petani seharusnya lebih mengikuti perkembangan harga dipasar, sehingga petani dapat } \\
\text { mengambil harga yang menguntungkan dari fluktuasi harga yang terjadi di pasar. }\end{array}$ \\
\hline
\end{tabular}

\section{Abstract}

This study aims to determine: (1) market structure of red chilli production in Central Java. (2) Analyzing the transmission elasticity of red pepper price at farmer level and merchant level in Magelang, Temanggung and Brebes districts. Analyzer used is ratio concentration analysis (CRn) and analysis of price transmissionelasticity (Et) used simple linear regression. The results showed that (1) The structure of the production market thatwas formed in central Java was generally strictly oligopsoni. (2) The result of price transmission elasticityconduded that in Magelang District Temanggung is elastic $(E>1)$. While Brebes is inelastic $(E<1)$ which means the sensitivity of price changes at the farm level is smaller than the price change at the merchant level. Farmersas producers have not received a good price paid by traders. Farmers should keep abreast of market prices, sofarmers can take advantageous prices of market price fluctuations.

Ruang Jurnal Gedung L FE UNNES, Sekaran Gunungpati

Semarang, 50229, Indonesia

E-mail: tiaraadikusumah@yahoo.co.id 


\section{PENDAHULUAN}

Cabai merupakan komoditas unggulan holtikultura yang dibudidayakan, dikembangkan, dan dikonsumsi oleh masyarakat luas untuk pemenuhan kebutuhan. Salah satu komoditas yang potensial untuk dikembangkan adalah komoditas cabai merah (Dirjen Hortikultura). Pengembangan cabai merah sangat potensial ke depannya baik dalam bentuk usaha tani (on-farm) maupun dalam bentuk usaha di luar usaha tani (off-farm). Irawan (2007) menjelaskan bahwa pengembangan hortikultura pada umumnya lebih banyak dijumpai pada aspek off-farm yaitu penanganan pasca panen dan pemasaran dikarenakan karakteristiknya yang cepat rusak (perishable). Oleh karena itu kebijakan pembangunan pertanian yang hanya difokuskan pada aspek produksi atau usaha tani belum mampu mendorong pertumbuhan secara berkelanjutan selama permasalahan off-farm belum dapat diatasi. Permasalahan off-farm yang sering terjadi pada sayuran khususnya pada cabai merah adalah harga.

Menurut badan pusat statistik, Jawa Tengah merupakan salah satu provinsi penghasil cabai merah di Indonesia. Produksi cabai merah di Jawa tengah berada pada kabupaten Kabupaten Magelang, Temanggung dan Brebes yang merupakan kabupaten penghasil cabai merah di Jawa Tengah dengan produksi dengan rata-rata produksi terbesar diantara kabupaten lainnya dan memiliki kontribusi terhadap produksi Jawa Tengah. Namun produksi cabai merah di Jawa tengah masih menunjukan tren yang berfluktuasi. Hal ini dikarenakan karena faktor cuaca yang tidak mendukung, yang berpengaruh terhadap produksi cabai merah. Kondisi ini juga merupakan dampak dari adanya harga cabai merah yang tidak pasti dari musim ke musim, kondisi yang menjadikan petani cabai merah sering mengalami kegelisahan saat musim tanam cabai tiba. Ketika harga pada musim sebelumnya turun maka akan mempengaruhi psikologis petani pada masa tanam berikutnya, hal ini sesuai dengan pernyataan Arifien dalam (Jannah dkk, 2015) yang menyatakan jatuhnya harga pada tahun sebelumnya akan diikuti dengan penurunan luas areal dan produksi. Cabai merah merupakan salah satu komoditas holtikultura yang memiliki fluktuasi dan sensitivitas harga yang tinggi. Fluktuasi harga cabai tentunya sangat merugikan petani dan konsumen, karena Kenaikan harga cabai belum tentu dinikmati oleh petani. Hal ini di karenakan adanya margin harga antara petani dan konsumen.

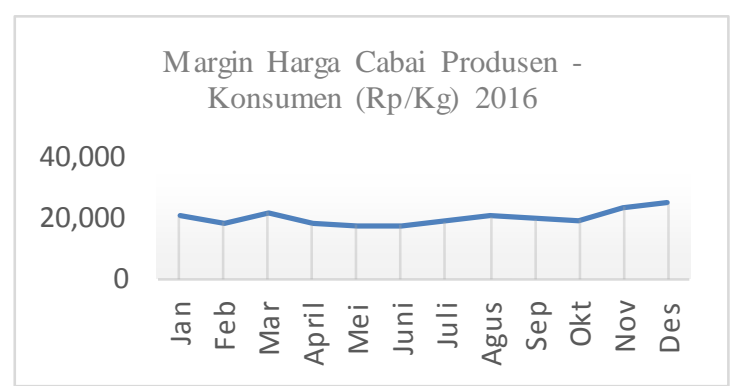

Gambar 1. Margin Harga

Sumber : Badan pusat statistik

Adanya perbedaan perbedaan harga atau selisih harga yang dibayar konsumen dengan harga yang diterima petani produsen menggambarkan bahwa harga yang di terima konsumen bukanlah harga yang sesungguhnya petani. Agustian dkk, (2008), menyatakan bahwa ketimpangan perolehan pendapatan ini disebabkan karena cukup panjangnya rantai pemasaran, sehingga pemasaran cabai merah dirasakan masih belum efisien. Conforti (2004) dalam Ruslan (2016) menjelaskan bahwa disparitas harga dapat disebabkan oleh dua faktor yaitu yang pertama adalah jalur pemasaran yang panjang dan yang kedua adalah adanya market power yang dimiliki oleh pedagang perantara. Yustiningsih (2012) menyatakan bahwa market power yang dimiliki oleh pedagang akan menyebabkan semakin tingginya margin distribusi dan transmisi harga yang tidak simetris dan menunjukan bahwa pasar yang dihadapi pasar yang terkonsentrasi dan menunjukan bahwa power yang dimiliki oleh pedagang bisa menetapkan harga untuk memaksimalkan keuntungannya. Adanya permasalahan harga yaitu fluktuasi harga pada 
komoditi cabai merah maka untuk itu akan diangkat sebagai sebuah penelitian. Harga yang baik tentunya menjadi suatu harapan bagi petani, dan menjadi faktor yang memberi semangat petani untuk kegiatan bertani. Oleh karena itu, penelitian ini bertujuan untuk mengkaji Struktur Pasar komoditas cabai merah dan elastisitas trasnmisi harga yang terjadi antara petani dan pedagang.

\section{METODE PENELITIAN}

Jenis data yang digunakan dalam penelitian ini adalah data sekunder, dimana data yang diperoleh diwujudkan dalam bentuk angka. Penelitian ini menggunakan data data produksi cabai merah pada tahun 2013 s.d 2016 untuk mengetahui struktur pasar produksi dan jumlah pedagang yang menyerap produksi petani. Sedangkan untuk menganalisis elastisitas transmisi harga digunakan data harga petani dan harga pengecer pada bulan Juni 2016 s.d Januari 2017. Data runtut waktu (time series) adalah data yang secara kronologis disusun menurut waktu pada satu variabel tertentu.

Metode yang digunakan untuk menganalisis struktur pasar cabai merah dan transmisi harga antara produsen dan pedagang digunakan pengkuran konsentrasi rasio dan Analisis elastisitas transmisi harga melalui program SPSS 23.0 for windowsdan digunakan beberapa model analisis kuantitatif, yaitu :

\section{Rasio konsentrasi (CR)}

Untuk melihat struktur pasar cabai merah, akan dilakukan pengukuran rasio konsentrasi pasar yang didefinisikan sebagai jumlah dan ukuran distribusi penjual dan pembeli dalam pasar, semakin tinggi nilai konsentrasi rasionya, maka kemungkinan pasar semakin tidak kompetitif. Pengukuran konsentrasi rasio dilakukan dengan rumus sebagai berikut: Untuk Petani

$C R_{n}=\frac{M S 1+M S 2+M S 3}{M S i} \times 100 \%$

Keterangan:

MS1 : Produksi terbesar ke-1

MS2 : Produksi terbesar ke-2
MS3 : Produksi terbesar ke-3

MSi : Seluruh produksi yang ada

Untuk Pedagang

$C R n=\frac{M S 1+M S 2+M S 3}{M S i} \times 100 \%$

Keterangan :

MS1 : Pembelian pedagang ke-1

MS2 : Pembelian pedagang ke-2

MS3 : Pembelian pedagang ke-3

MSi : Total pembelian

Nilai $\mathrm{CR}_{3}$ akan menunjukan presentase output pasar yang dihasilkan oleh tiga produksi terbesar di di Jawa Tengah. Semakin besar nilai rasio konsentrasi menunjukan bahwa industri tersebut semakin terkonsentrasi dan semakin sedikit jumlah pedagang yang berada di pasaran. Sedangkan semakin rendah rasio konsentrasi menunjukan pasar bersaingan yang lebih kompetitif dikarenakan tidak ada pedagang secara signifikan yang menguasai pasar.

\section{Elastisitas Transmisi harga}

Untuk menganalisis transmisi harga antara petani dan pedagang dilakukan dengan menggunakan Analisis elastisitas transmisi harga. Analisis elastisitas transmisi harga adalah analisis yang menggambarkan sejauh mana dampak perubahan harga suatu barang di satu tempat atau tingkatan terhadap perubahan harga barang itu di tempat atau tingkatan lain. Untuk mengetahui besarnya elastisitas transmisi harga (Eth) digunakan persamaan dengan menghubungkan antara harga di tingkat produsen $(\mathrm{Pf})$ dan harga ditingkat pengecer $(\mathrm{Pr})$. Transmisi harga diukur melalui regresi sederhana di antara dua harga pada dua tingkat pasar, kemudian dihitung. Secara matematis elastisitas transmisi harga (Et) dapat dituliskan sebagai :

$\mathrm{Pf}=\mathrm{b} 0+\mathrm{b} 1 \mathrm{Pr}$

Ditransformasikan dalam bentuk linear menjadi

Ln Pf $=\ln b 0+b 1 \ln P r$

Dimana : b0 : intersep

b1 : Koefisien elastisitas transmisi harga

Pf : Harga tingkat pedagang

Pr : Harga tingkat petani 
Kriteria pengukuran analisis elastisitas transmisi harga :

Et $=1$, maka laju perubahan harga ditingkat produsen sama dengan laju perubahan harga di tingkat pedagang.

Et $<1$, maka laju perubahan harga ditingkat pedagang lebih kecil dibandingkan dengan laju perubahan harga di tingkat produsen.

Et $>1$, maka laju perubahan harga ditingkat pedagang lebih besar dibandingkan dengan laju perubahan harga ditingkat produsen.

\section{HASIL DAN PEMB AHASAN}

\section{Analisis Rasio Konsentrasi Produksi Cabai Merah Jawa Tengah}

Permasalahan yang terjadi pada petani cabai merah adalah rendahnya harga yang diperoleh petani tidak sebanding dengan harga yang diperoleh oleh para pedagang. Walaupun cabai merah merupakan komoditi yang cukup menjanjikan hasilnya, namun perannya dalam meningkatkan kesejahteraan petani belum signifikan.

Masalah mendasar yang dihadapi oleh petani adalah menghadapi pasar yang sudah terkonsentrasi oleh pedagang, dikarenakan jumlah pedagang lebih sedikit dari pada pedagang sehingga petani yang jumlah lebih banyak memiliki ketergantungan terhadap pedagang. Menururt Prasetyo (2010) pengukuran konsentrasi (CRn) bertujuan untuk mengetahui ciri-ciri struktur pasar, analisis struktur pasar bisa dilihat menggunakan pendekatan rasio konsentrasi, semakini tinggi nilai konsentrasinya maka pasar tersebut cenderung berbentuk pasar persaingan yang tidak sempurna atau oligopoli/oligopsoni.

Berdasarkan hasil analisis $\mathrm{CR}_{3}$ Provinsi Jawa Tengah yang meliputi Kabupaten Magelang, Temanggung dan brebes diperoleh nilai rata-rata konsentrasi rasio nya sebesar $69 \%$ yang menunjukan bahwa struktur pasar yang terjadi dalam pasar cabai merah di Jawa Tengah bersifat oligopsoni ketat, kemudian untuk hasil analisis konsentrasi rasio Kabupaten Magelang, Temanggung dan Brebes bisa dilihat pada tabel 1.
Tabel 1. Tingkat Rasio Konsentrasi

\begin{tabular}{lll}
\hline Kabupaten & Petani & Pedagang \\
& & \\
\hline Magelang & $56 \%$ & $76 \%$ \\
Temanggung & $42 \%$ & $67 \%$ \\
Brebes & $63 \%$ & $66 \%$ \\
\hline
\end{tabular}

Berdasarkan hasil analisis pada tabel 1 terlihat bahwa struktur pasar yang terjadi dalam pasar cabai merah di Kabupaten Magelang dan Temanggung bersifat oligopsoni ketat dengan rata-rata nilai konsentrasi rasio petani sebesar $53 \%$ dan pedagang sebesar $69 \%$.

Elastisitas Transmisi Harga Cabai Merah di Kabupaten Magelang, Temanggung dan Brebes

Analisis elastisitas transmisi harga digunakan untuk mengetahui presentasi perubahan harga ditingkat petani akibat perubahan harga di tingkat pedagang melalui nilai elastisitas transmisi harga. Nilai ini menunjukan rasio perubahan relatif harga di tingkat petani dengan perubahan harga di tingkat pedagang. Pengertian ini erat kaitannya dengan anggapan bahwa marjin harga merupakan akibat adanya permintaan turunan dari pedagang kepada petani sebagai produsen. Adapun hasil estimasinya sebagai berikut:

\section{Kabupaten Magelang}

Tabel 2. Analisis Regresi Elastisitas Transmisi Harga Pemasaran Cabai Merah di Kabupaten Magelang

\begin{tabular}{ll}
\hline Variabel Bebas & Koefisien Regresi \\
\hline Harga Pedagang & 1,120 \\
Konstanta & $-1,399$ \\
$\mathrm{R}^{2}$ & 0,99 \\
DW & 1,520 \\
\hline
\end{tabular}

Analisis elastisitas transmisi harga digunakan untuk mengetahui respon harga cabai merah ditingkat petani karena perubahan harga ditingkat pedagang Pengecer. Elstisitas transmisi harga dapat dilihat dari hasil regresi linier sederhana, untuk mengetahui hasil analisis regresi linear sederhana digunakan program Komputer SPSS 23. Hasil elastisitas transmisi harga dapat dilihat pada Tabel 2. 
Berdasarkan tabel 2 hasil analisis regresi sederhana diperoleh koefisien regresi b1 sebesar 1,120 nilai koefisien regresi b1 ini menunjukkan nilai elastisitas transmisi harga yang bersifat (elastis). Diperoleh nilai elastisitas transmisi harga lebih besar dari satu (Et>1) dapat diartikan bahwa perubahan harga sebesar $1 \%$ di tingkat pedagang pengecer akan mengakibatkan perubahan harga lebih besar dari 1,120 di tingkat petani. Hal ini menunjukan bahwa kepekaan perubahahan harga di tingkat petani lebih besar dari pada perubahan harga ditingkat pedagang. Indikasi ini menunjukan bahwa di dalam pemasaran cabai merah di Kabupaten Magelang, pedagang dan lembaga pemasaran cukup kompetitif dalam membeli cabai merah dari petani. Sesuai dengan struktur pasar yang dihadapinya yaitu oligopsony ketat.

\section{Kabupaten Temanggung}

Analisis elastisitas transmisi harga digunakan untuk mengetahui apakah perubahan harga cabai merah di tingkat pedagang pengecer ditransmisikan dengan baik kepada petani cabai merah di Kabupaten Temanggung. Berdasarkan perhitungan yang dilakukan, hasil estimasinya sebagai berikut.

Tabel 3. Analisis Regresi Elastisitas Transmisi Harga Pemasaran Cabai Merah di Kabupaten

\begin{tabular}{ll}
\multicolumn{2}{c}{ Temanggung } \\
\hline Variabel Bebas & $\begin{array}{l}\text { Koefisien } \\
\text { Regresi }\end{array}$ \\
& 1,017 \\
Harga Pedagang &,- 204 \\
Konstanta & 0,772 \\
$\mathrm{R}^{2}$ & 2,274 \\
$\mathrm{DW}$ & \\
\hline
\end{tabular}

Berdasarkan tabel 3 hasil analisis regresi sederhana di atas, maka elastisitas transmisi harga antara petani dengan pedagang pengecer adalah sebesar koefisien regresi yaitu Et $=1,017$ $>1$ (elastis). Jadi nilai Et sebesar 1,017 (lebih besar dari satu) menunjukkan bahwa perubahan harga ditingkat produsen lebih besar dari pedagang. pedagang lemah sehingga. Bila terjadi perubahan harga cabai merah ditingkat pedagang sebesar $1 \%$, maka harga cabai merah di tingkat petani berubah sebesar 1,017. Dilihat dari koefisien determinasi $\left(\mathrm{R}^{2}\right)$, respon harga cabai merah di tingkat petani karena perubahan harga ditingkat pedagang adalah sebesar 0,772 berarti $77,0 \%$ variasi harga di tingkat petani dipengaruhi oleh variasi harga di tingkat pedagang, sedangkan $23 \%$ dipengaruhi oleh variabel lainnya.

\section{Kabupaten Brebes}

Analisis elastisitas transmisi harga digunakan untuk mengetahui persentasi perubahan harga ditingkat produsen akibat perubahan harga ditingkat pedagang, dengan digunakan model $\ln \mathrm{Pf}=\mathrm{b} 0+\mathrm{b} 1 \mathrm{ln} \mathrm{Pr}$. Sudiyono dalam suharyanto (2005) menyatakan bahwa pada umumnya nilai elastisitas transmisi ini lebih kecil daripada satu, artinya volume dan harga input konstan maka perubahan nisbi harga ditingkat pengecer tidak akan melebihi perubahan nisbi harga ditingkat petani. Adapun hasil estimasinya dapat dilihat pada tabel 4 .

Tabel 4. Analisis Elastisitas Transmisi Harga Pemasaran Cabai Merah di Kabupaten Brebes

\begin{tabular}{ll}
\hline Variabel Bebas & $\begin{array}{l}\text { Koefisien } \\
\text { Regresi }\end{array}$ \\
\hline Harga Pedagang & 0,837 \\
Konstanta & 0,628 \\
R $^{2}$ & 0,679 \\
DW & 1,972 \\
\hline
\end{tabular}

Berdasarkan tabel 4 hasil perhitungan terlihat bahwa nilai elastisitas transmisi harga dari pedagang ke petani sebesar 0,837. Nilai elastisitas transmisi harga bernilai $0,837 \mathrm{E}<1$ (inelastis) menunjukkan bahwa apabila terjadi perubahan harga cabai merah ditingkat pedagang pengecer sebesar 1\% maka harga ditingkat petani akan berubah sebesar $0,837 \%$ dalam hubungan yang searah. Nilai 0,837 \% kurang dari angka 1\% maka dapat dinyatakan bahwa perubahanperubahan harga ditingkat pedagang tidak ditransmisikan dengan baik ke harga ditingkat petani. Dari angka elastisitas transmisi harga kurang dari 1\% maka dapat dinyatakan bahwa kepekaan perubahan harga ditingkat petani lebih kecil dari pada perubahan harga ditingkat pedagang. 


\section{HASIL DAN PEMB AHASAN}

\section{Analisis Rasio Konsentrasi Produksi Cabai Merah di Jawa Tengah}

Konsentrasi merupakan kombinasi pangsa pasar dari beberapa wilayah yang mempunyai produksi terbesar dimana mereka menyadari adanya saling ketergantungan. Analisis struktur pasar pada pembahasan ini adalah dengan menggunakan rasio konsentrasi dilakukan pada tiga wilayah yang mempunyai produksi cabai merah terbesar $\left(\mathrm{CR}_{3}\right)$. Prasetyo (2010) menyatakan bahwa penggabungan empat atau lebih wilayah produksi yang memiliki pangsa pasar 60 sampai $100 \%$ menghasilkan struktur pasar yang bersifat oligopoli ketat, dimana kesepakatan diantara mereka untuk menetapkan harga relatif mudah. Namun untuk penggabungan empat wilayah yang mempunyai produksi terbesar yang memiliki pangsa pasar $40 \%$ atau kurang dari pangsa pasar menghasilkan struktur pasar yang bersifat oligopoli/oligopsoni longgar.

Berdasarkan jumlah produksi terdapat tiga kabupaten yang memiliki produksi terbesar diantaranya Kabupaten Magelang, Temanggung, dan Brebes. Kabupaten tersebut menggambarkan dari produksi cabai merah yang ada di Jawa Tengah sehingga melalui pendekatan $\mathrm{CR}_{3}$ akan digunakan untuk melihat presentase total output tiga wilayah produksi terbesar terhadap total output keseluruhan produksi. Nilai rasio konsentrasi yang dimiliki oleh pedagang memiliki nilai rata-rata sebesar $53 \%$ dan pedagang sebesar $69 \%$. Hal ini menunjukan bahwa ketiga produksi terbesar memiliki persaingan dalam pasar oligopsoni ketat. Sehingga pasar terkonsentrasi dan pedagang memiliki kekuatan untuk menentukan harga.

Prastowo (2008) menyebutkan bahwa struktur pasar sangat mempengaruhi besar atau kecilnya margin keuntungan yang dapat ditentukan oleh beberapa kriteria yaitu (1) jumlah perusahaan yang beroperasi di pasar, (2) ada tidaknya hambatan bagi perusahaan untuk masuk pasar dan keluar dari pasar, dan (3) karakteristik produk yang diperdagangkan.
Struktur pasar tersebut selanjutnya berpengaruh terhadap kekuatan dari para perusahaan di dalamnya untuk mempengaruhi pasar. Sedangkan kasus pada komoditas cabai merah pada kondisi pasar dengan intensitas persaingan tinggi terlihat di level petani saat panen raya.

Homogenitas dan melimpahnya cabai merah di pasaran menyebabkan petani tidak mempunyai kekuatan untuk menetapkan harga, sehingga petani terpaksa menjadi price taker. Sebaliknya pada level pedagang yang jumlahnya lebih sedikit akan cenderung memiliki kekuatan untuk mempengaruhi harga. Bahkan seringkali pedagang membentuk kartel dengan membuat kesepakatan harga di pasar. Petani juga dihadapkan pada fungsi penawaran yang inelastis, dimana tidak dapat menambah hasil produksinya pada saat terjadi kenaikan harga cabai merah di pasaran. Fluktuasi harga yang terjadi tidak dinikmati oleh petani. Hal ini disebabkan oleh karena petani tidak bermain langsung di pasar, kenaikan harga hanya dinikmati oleh spekulan, tengkulak dan distributor. (Prajanti, 2012).

Berdasarkan nilai rasio konsentrasi pedagang sebebesar $69 \%$, menunjukkan bahwa struktur pasar Kabupaten Magelang dan Temanggung dan Brebes berbentuk oligopsoni ketat, dimana pasar berbentuk pasar persaingan tidak sempurna dan terkonsentrasi. Pagala dkk, (2017) menyatakan bahwa pasar yang dihadapi petani adalah pada persaingan tingkat kecil dan terkonsentrasi. Hal ini menyebabkan pedagang sebagai penjual memiliki kemungkinan untuk melakukan kesepakatan dalam mengendalikan harga pasar dengan pedagang lainnya, pedagang mempunyai pengaruh besar dalam pemasaran. Sisfahuni dkk (2011) penelitian yang berjudul Kelembagaan Pemasaran Kakao Biji Tingkat Petani Kabupaten Parigi Moutong Provinsi Sulawesi Tengah, menyatakan bahwa permasalaha yang dihadapi petani selain produktivitas yang rendah, petani juga harus menghadapi pasar persaingan yang tidak sempurna.

Semakin tinggi tingkat konsentrasi, akan semakin mudah pedagang memaksimalkan keuntungannya. Hal ini berarti tingkat 
konsentrasi yang, semakin mudah pedagang mempengarui petani. Kondisi ini di maknai semakin besar kekuatan yang dimiliki oleh pedagang terhadap petani sebagai produsen. Ketika petani mulai terpedaya oleh pedagang maka pedagang dengan leluasa dalam menentukan tingkat harga terhadap produk yang dihasilkan petani. Hal ini tentunya sangat merugikan petani yang sudah susah payah menanam dan merawat cabai merah tersebut. pasar persaingan yang berbentuk oligopsoni tentunya merugikan petani. Petani tidak mempunyai pilihan lain selain menjual produksinya dengan harga yang rendah kepada pedagang karena petani biasanya sudah terjalin kontrak dengan pedagang.

Konsekuensi yang dihadapi petani sebagai produsen adalah menempati posisi tawar lemah dalam proses penentuan harga. Petani harus menghadapi harga jual yang rendah dan berhadapan dengan pilihan sulit, jika tidak menjual produknya, petani akan rugi dan tidak mempunyai modal untuk musim tanam selanjutnya atau bahkan petani tidak mempunyai penghasilan untuk memenuhi kebutuhan seharihari.

Pedagang mempunyai kemampuan menekan petani dalam hal menentukan harga komoditas, tapi kenyataannya petani begitu dekat dengan mereka, pedagang adalah penguasa pasar sebenarnya di lapangan. Terkadang, pedagang merangkap juga petani produktif namun memiliki kemampuan kewirausahaan lebih baik dibandingkan petani lain di daerahnya. Keterikatan petani pada pedagang dalam menjual hasil usahatani membuat petani selalu kalah dan tidak berdaya di pasar.

Petani tidak bisa menjadi penentu harga karena adanya keterikatan antara petani dan pedagang dalam kegiatannya, kebutuhan yang mendesak membuat petani mau tidak mau harus menerima harga dari para pedagang perantara. Adanya ketergantungan petani terhadap pedagang menjadi bukti bahwa pedagang memiliki pengaruh yang kuat. Peran pedagang tidak dipungkiri dibutuhkan oleh para petani, khususnya petani yang berada di daerah yang jauh dari pusat kota atau pasar, mengingat sebagian petani tidak mempunyai kendaraan untuk mengangkut produksinya menuju pasar. Dalam hal finansial pedagang tentunya lebih unggul dibanding petani sehingga petani tak jarang meminjam uang untuk modal kepada pedagang, maka dari itu petani tidak mempunyai pilihan lain untuk menjalin hubungan dengan pedagang demi berlangsungnya kegiatan cocok tanamnya. Meskipun tak jarang sistem ijon sering di hadapi oleh para petani. Sistem ijon juga menjadi salah satu kendala bagi petani. Petani harus menjual produk sebelum masa panen, ini dilakukan karena kebutuhan jangka pendek mereka yang harus dipenuhi seperti harus menyekolahkan anak-anak dan memenuhi kebutuan sehari-hari. Dengan sistem ijon ini petani tentunya tidak bisa berperan dalam menentukan harga karena mereka berpikir bahwa harga telah ditentukan oleh pedagang, sehingga mereka harus menerima harga yang diberikan, petani masih jauh dari kata sejahtera, petani seperti hanya menjadi mesin penghasil bahan pangan. Padahal yang mempunyai resiko sangat tinggi itu adalah petani, Ketika terjadi serangan hama, pengaruh cuaca dan terjadi bencana, petani yang rugi. Sementara yang untung tetap mereka para pedagang dan tengkulak. Ketika terjadi serangan hama, pengaruh cuaca dan terjadi bencana, petani yang rugi. Sementara yang untung tetap mereka para pedagang dan tengkulak. Melimpahnya produksi seharusnya akan berpengaruh terhadap keuntungan yang akan diterima petani, namun pada kenyataanya produksi yang melimpah hanya akan menghadapi tekanan harga yang rendah. Keuntungan yang diterima tidak sebanding dengan biaya produksi petani dari awal tanam sampai panen. Penghasilan yang tak layak sering kali membuat petani menjual lahannya. Profesi petani tidak lagi dianggap sebagai profesi yang menjanjikan yang menyejahterakan petani, tidak salah jika generasi muda pun sudah jarang yang berminat menjadi petani. 


\section{Hambatan Masuk Pasar}

Sebagian orang mungkin menganggap menjadi petani merupakan pekerjaan yang di anggap rendah resiko dan minim kendala, namun dalam prakteknya terutama petani mengalami sejumlah hambatan. Hambatan yang pertama yaitu berasal dari karakteristik produk pertanian yang mudah rusak dan bersifat musiman. Kondisi tersebut mengakibatkan pada saat musim panen, produksi yang dihasilkan melimpah sehingga harga jual produk tersebut cenderung menurun.

Hambatan yang dihadapi selanjutnya adalah minimnya informasi pasar, dalam kegiatan pemasaran cabai merah, informasi pasar merupakan hal yang utama untuk petani, struktur pasar oligopsoni memungkinkan petani kesulitan untuk memperoleh informasi, terutama mengenai kondisi pasar dan perkembangan harga. Harga cabai merah yang cenderung fluktuatif membuat petani harus terus memantau informasi terbaru mengenai harga agar tidak dirugikan dalam transaksi-transaksi yang dilakukan dengan pelaku pasar lain. Sebagaimana dinyatakan Hutabarat dkk, (2004) petani-petani tidak memiliki informasi yang memadai tentang keadaan pasar dan teknologi pascapanen dan pengolahannya untuk menampung kelebihan pasokan sehingga pada saat berikutnya mereka menyesuaikan produksi. Hal ini tentunya menjadi menjadi peluang bagi pihak tertentu untuk memanfaatkan kondisi tersebut.

Terbukanya informasi mengenai pasar dan perkembangan harga komoditas cabai merah memungkinkan petani dapat melakukan perencanaan produksi yang baik. Petani dapat menentukan jenis komoditi apa yang akan produksi, berapa volumenya serta kualitas apa yang akan dihasilkan sesuai dengan permintaan pasar. Adanya informasi pasar yang memadai dapat mengurangi terjadi kelebihan penawaran pada komoditi yang satu dan terjadinya kelebihan permintaan pada komoditi yang lain pada saat bersamaan.Walaupun demikian, petani sangat membutuhkan peran pedagang dalam proses pendistribusian hasil-hasil pertaniannya selain itu, petani yang menjual langsung hasil panennya ke pusat pasar akan menemukan beberapa permasalahan, khususnya pada proses pengangkutan, dimana tidak sedikit petani yang tidak memiliki kendaraan untuk mengangkut hasil produksinya ke pusat pemasaran. ini disebabkan karena letak lokasi usaha tani antara satu petani dengan petani lain berjauhan dan mereka selalu berusaha untuk mencari lokasi penanaman yang sesuai dengan keadaan tanah dan iklim yang cocok untuk tanaman yang diusahakan.

Kondisi tersebut menyulitkan petani dalam hal transportasi dan pengangkutan. Pengangkutan tersebut akan mengeluarkan biaya tambahan untuk transportasi. Tingginya biaya pengangkutan, serta desakan oleh banyaknya kebutuhan yang harus dipenuhi inilah yang kemudian akhirnya mendesak petani untuk memilih menjual hasil pertaniannya melalui pedagang perantara.

Informasi pasar mengenai harga komoditas sangat minim di dapatkan oleh petani, petani hanya mendapatkan informasi dari sesama petani, atau dari televisi. Minimnya informasi mengenai pasar ini tentunya menjadi peluang bagi pedagang lebih menguasai informasi mengenai harga dan kondisi pasar dari pada petani. Sehingga pasar bersaing dalam bentuk pasar persaingan tidak sempurna (oligopsoni). Salah satu ciri dari pasar oligopsoni adalah langkanya informasi yang lengkap dan besarnya proporsi komoditas yang dibeli oleh hanya beberapa pedagang/pembeli saja.

Selain menghadapi masalah dari sisi pemasaran, petani juga masih menghadapi masalah dari aspek SDM petani itu sendiri, faktor SDM secara langsung berdampak pada kemampuan meningkat atau tidaknya kapasitas lahan usaha tani. Kemampuan peningkatan kapasitas lahan pada akhirnya akan berdampak pada produksi komoditas, Semakin baik kualitas SDM akan semakin baik dalam meningkatkan kualitas dan kuantitas hasil pertanian, yang pada akhirnya berdampak pada produksi komoditas cabai merah dan pendapatan yang di terima petani. 


\section{Elastisitas Transmisi Harga Cabai Magelang}

Komoditas pertanian khususnya cabai merah selalu mengalami perubahan, masalahnya adalah apabila semakin besar margin pemasaran maka akibatnya adalah bagian harga yang diterima oleh produsen adalah semakin kecil dan mengindikasikan bahwa sistem pemasaran yang tidak efisien atau tidak terjadi keterpaduan pasar dan mengindikasikan rendahnya balas jasa atau bagian harga yang diterima oleh petani, hal tersebut sesuai dengan yang dinyatakan oleh Rahayu (2009), yang mengemukakan bahwa yang menyebabkan tidak efisiennya pemasaran produk pertanian adalah karena rendahnya tingkat balas jasa yang diterima oleh petani atau bagian harga yang diterima oleh petani, selain itu lemahnya posisi petani disebabkan oleh posisi tawar yang rendah akibat over supply yang sering terjadi pada panen raya sehingga menyebabkan rendahnya harga yang diterima petani.

Hasil penelitian menunjukan bahwa pemasaran cabai merah bersifat elastis. Elastisitas transmisi cabe merah sebesar 1,120 artinya perubahan harga sebesar $1 \%$ di tingkat pedagang akan mengakibatkan perubahan harga sebesar 1,120 di tingkat petani. Selain menunjukkan besarnya perubahan harga ditingkat petani dan pedagang, nilai elastisitas transmisi harga juga dapat menyatakan tingkat kompetisi suatu pasar, penampakan atau struktur pasar yang terbentuk. Nilai elastisitas transmisi harga sebesar 1,120 (lebih besar dari satu) mengindikasikan bahwa yang artinya kepekaan perubahan harga di tingkat petani lebih besar dari pada perubahan harga di tingkat pedagang, pasar yang dihadapi adalah pasar tidak sempurna. Kondisi ini tentunya sedikit menguntungkan petani sebagai produsen, hal ini terjadi karena Kabupaten Magelang memiliki jumlah prduksi terbesar di Jawa Tengah, Produksi merupakan salah satu faktor pendukung agar petani mempunyai posisi tawar yang lebih baik, jumlah produksi yang cukup tinggi kan meningkatkan harga jual cabai merah, terutama pada saat-saat pasokan cabai merah sedang langka dipasaran. peningkatan produksi akan berdampak baik terhadap pendapatan yang diterima petani, sehingga petani mampu menutupi biaya selama proses bertaninya. (Prayitno dkk, 2013)

\section{Elastisitas Transmisi Harga Temanggung}

Saat ini terjadi perubahan orientasi dalam kegiatan pertanian, dari pertanian yang berorientasi kepada produksi menuju pertanian yang berorientasi pasar. Perubahan orientasi tersebut sampai saat ini masih menemui berbagai kendala salah satunya adalah bargaining power petani yang rendah yang diakibatkan dikuasainya kendali pemasaran oleh pelaku pemasaran (Direktorat Jendral Pemasaran, 2006). Berhasilnya kegiatan usaha tani tidak akan mendorong kesejahteraan petani apabila tidak didukung oleh pemasaran yang baik. Menurut dalam konsep agribisnis, pasar harus ditempatkan pada ururan terdepan. Pemasaran merupakan salah satu subsistem penting dalam sistem agribisnis, pemasaran yang efisien akan meningkatkan kinerja usaha tani, akan tetapi sebaliknya apabila tidak efisien maka akan menurunkan kinerja usahatani tersebut. Sebagai komoditas pertanian, harga beberapa produk sayuran selalu mengalami mengalami fluktuasi yang biasanya diluar kendali petani. Fluktuasi harga sayuran pada umumnya lebih tinggi dibanding buah, padi dan palawija dengan kata lain ketidakseimbangan antara volume pasokan dan kebutuhan konsumen lebih sering terjadi pada sayuran (Irawan, 2007). Harga produk pertanian tergolong sangat fluktuatif dengan rentang tingkat harga yang sangat lebar, apalagi setelah dikaitkan dengan future trading. Pada waktu tertentu, seperti musim panen dan musim hujan harganya bisa sangat rendah namun pada saat yang lain bisa sangat tinggi. Harga yang sangat fluktuatif secara teoritis akan menyulitkan prediksi bisnis, baik perhitungan laba rugi maupun manajemen resiko.

Berdasarkan hasil analisis maka dapat dikatakan bahwa elastisitas transmisi harga cabai merah sebesar 1,017>1 atau $\mathrm{E}>1$. Hal ini menunjukan bahwa transmisi harga diteruskan dengan baik oleh pedagang. Hal ini dikarenakan petani dalam menjual produknya kepada pedagang langganannya, petani yang telah lama berlangganan baik dengan pedagang akan lebih 
akrab sehingga saat menjual produk usaha taninya akan terjadi tawar menawar dan pedagang akan bertindak lebih bijaksana dalam menetapkan harga dengan langganan. Petani telah menjalin hubungan baik dengan pedagang sehingga hubungan ini nantinya akan memberikan pengaruh pada harga jual cabai di tingkat petani. Hal ini menunjukkan bahwa pedagang membeli produk petani secara kompetitif. (Rindayanti dkk, 2010).

Harga jual cabai pada petani yang sudah berlanggan akan lebih tinggi jika dibandingkan petani yang tidak berlanggan. Kondisi ini juga sebenarnya ada sisi tidak baiknya nya karena petani hanya melakukan transaksi dengan satu pedagang saja dan tidak berhubungan dengan pedagang lain meskipun menawarkan harga yang lumayan tinggi, kondisi ini membuktikan bahwa dengan berlangggan menjadikan salah satu penyebab kedekatan antara petani dan pedagang, sehingga pedagang ada perasaan tidak tega untuk menekan harga cabai pada petani.

\section{Elastisitas Transmisi Harga B rebes}

pemasaran komoditas cabai merah transmisi dari harga dari pasar pengecer ke produsen yang relatif rendah merupakan salah satu indikator yang mencerminkan adanya kekuatan monopoli/oligopsoni pada pedagang. Hal ini karena pedagang yang memiliki kekuatan monopoli atau oligopsoni dapat mengendalikan harga beli dari petani sehingga walaupun harga ditingkat konsumen relatif tetap tetapi pedagang dapat menekan harga beli dari petani untuk memaksimumkan keuntungannya. Begitu pula bila terjadi kenaikan harga ditingkat konsumen maka pedagang tidak meneruskan kenaikan harga tersebut pada petani secara sempurna, dengan kata lain kenaikan harga yang diterima petani lebih rendah dari pada kenaikan harga ditingkat pengecer. Bentuk transmisi harga ini tidak menguntungkan bagi petani cabai merah karena kenaikan harga yang terjadi ditingkat pengecer tidak sepenuhnya dinikmati oleh petani. Walupun kenaikan harga tersebut diteruskan, tetapi dilakukan secara lambat dan tidak sempurna. Begitu juga seterusnya hingga sampai pada petani.
Petani selaku produsen yang berada ditingkat paling bawah hanya bisa menerima harga yang diberikan dari pedagang pengumpul desa. Sebaliknya jika terjadi penurunan harga, petani merupakan lembaga yang pertama merasakan penurunan harga yang terjadi. Pada dasarnya dengan kekuatan oligopsoni kenaikan harga ditingkat ditingkat petani relatif kecil dari pada tingkat pengecer akibat perilaku pedagang yang berusaha memaksimumkan keuntungan dengan memberikan informasi harga yang tidak sempurna untuk menekan harga beli dari petani (Irawan, 2007).

Berdasarkan hasil peelitian transmisi harga dari tingkat pengecer kepada petani hanya sebesar 0,837 atau $\mathrm{E}<1$ yang berarti bahwa apabila terjadi perubahan harga cabai merah ditingkat pedagang pengepul sebesar $1 \%$ maka harga ditingkat petani akan berubah sebesar 0,837\%, dari angka elastisitas transmisi harga kurang dari 1\% maka dapat dikatakan bahwa kepekaan perubahan harga ditingkat petani lebih kecil dari pada perubahan harga ditingkat pedagang. Hal ini di pengaruhi oleh adanya kekuatan oligopsoni dari pedagang sehingga mereka mengendalikan harga beli dari petani atas harga tingkat produsen. Akibatnya posisi tawar petani yang lemah terkait dengan berbagai kendala yang dihadapi maka proses transmisi harga tersebut bersifat asimetri dimana penurunan harga diteruskan kepada petani secara cepat dan sempurna, sedangkan kenaikan harga diteruskan kepada petani secara lambat dan tidak sempurna.

Konsekuensinya petani sering mengalami harga dan ketidakpastian pendapatan petani relatif tinggi, akibat fluktuasi harga yang tinggi apalagi dalam komoditas cabai merah yang merupakan tanaman musiman dan kuantitasnya bersifat fluktuatif. Singh dalam made ayu (2016) mengatakan bahwa fluktuasi harga yang tinggi di sektor pertanian merupakan suatu fenomena yang umum akibat ketidakstabilan (inherentinstability) pada sisi penawaran. Hal ini berarti harga hasil pertanian disebabkan oleh sifat alami dari produksi pertanian, yaitu dalam jangka pendek tidak dapat merespon tambahan permintaan atau tidak dapat mengurangi 
produksi pada saat harga yang rendah. Pengaruh fluktuasi harga pertanian lebih besar bila dibandingkan dengan fluktuasi produksi. Keadaan ini dapat menyebabkan petani menderita kerugian dalam jangka pendek sehingga menimbulkan kurangnya keinginan untuk melakukan investasi di sektor pertanian atau petani akan beralih ke bidang lain.

\section{SIMPULAN}

Berdasarkan hasil analisis data dan pembahasan dalam penelitian transmisi harga cabai merah di Provinsi Jawa Tengah, maka dapat disimpulkan bahwa struktur pasar cabe merah di Jawa Tengah cenderung menunjukan bentuk struktur pasar oligopsoni ketat, lastisitas transmisi harga cabai merah di Kabupaten Magelang dan Temanggung menunjukan nilai E $>1$ (elastis). Sedangkan pada Kabupaten Brebes memiliki nilai elastisitas transmisi harga kurang dari 1 (inelastis).

Struktur pasar cabai merah di Jawa Tengah bersifat oligopsony ketat. Untuk meningkatkan posisi tawar petani cabai merah yaitu petani seharusnya lebih memperhatikan penetapan kualitas dan kuantitas produk, sehingga hal ini dapat meningkatkan posisi tawar petani dalam hal penentuan harga dan nilai barang.

Elastisitas transmisi pada Kabupaten Magelang dan Temanggung bersifat elastis. Sedangkan untuk Kabupaten Brebes memiliki nilai transmisi harga $\mathrm{E}<1$. Hal ini tentunya kurang menguntungkan bagi petani sebagai produsen, untuk meningkatkan pendapatan, petani sebagai produsen seharusnya lebih mengikuti perkembangan harga di pasar, sehingga petani dapat mengambil harga yang mengutungkan dari fluktuasi harga yang terjadi di pasar.

\section{DAFTAR PUSTAKA}

Agustian, Adang \& Setiajie, Iwan. (2008) Analisis Perkembangan Harga dan Ratai Pemasaran Komoditas Cabai Merah Di Provinsi Jawa Barat. Penelitian Pusat analisis social dan kebijakan Pertanian.

Hutabarat, Budiman \& Rahmanto, Bambang (2004). Dimensi Oligopsonistik Domestik Cabai Merah. Pusat penelitian dan Pengembangan Sosial Ekonomi Pertanian Badan Litbang Departemen Pertanian, Bogor.

Irawan.,2007. Fluktuasi Harga,Transmisi Harga, dan Marjin Pemasaran Sayuran dan Buah. Analisis Kebijakan Pertanian 5(4):358-373.

Pagala, M.Arman, Hadayani, Kalaba Y. (2017). Analisis Struktur Pasar Bawang Merah Varietas Lembah Palu Di Kabupaten Sigi. Jurnal Agroland 24 (2) : 128 - 137. Palu: Universitas Tadulako

Prajanti, Sucihatingsih dan Setiawan, Avi. (2012). Ekonomi Pertanian (Sebuah Pendekatan Empiris). Semarang : Unnes Press.

Prastowo, N. J., Yanuarti, T. dan Depari, Y. 2008. Pengaruh distribusi dalam pembentukan harga komoditas dan implikasinya terhadap inflasi. WorkingPaper. Bank Indonesia.

Prasetyo P.,Eko. (2010). Ekonomi Industri (sebuah aplikasi teori ekonomi mikro serta pengembangan pengamalan penelitian). Yogyakarta : Beta Offset.

Prayitno, A., Hasyim, A., Situmorang, S. (2013). Efisiensi Pemasaran Cabai Merah Di Kecamatan Adiluwih Kabupaten Pringsewu Provinsi Lampung. JIIA, Vol. 1 No. 1, Lampung: Universitas Lampung.

Rindayanti, W., Cyrilla, L. (2010). Analisis Efisiensi Pemasaran Ternak Potong Sapi Madura di Kabupaten Pamekasan. Med.Pet. Vol. 24. No.1. Bogor: Institut Pertanian Bogor.

Ruslan, Arifin Janur. (2016). Transmisi Harga dan Perilaku Pasar Bawang Merah. Tesis. Bogor : Institut Pertanian Bogor.

Rahayu. (2009). Analisis Efisiensi Pemasaran Jagung (Zea mays) Di Kabupaten Grobogan (Studi Kasus di Kecamatan Geyer). Program Studi Fakultas Pertanian. Universitas Sebelas Maret Sukarta. 